\title{
C orrelation of IP-10 gene expression with Serum alanine transaminase (ALT) levels and Hepatitis B viral load in cirrhosis and hepatocellular carcinoma (HCC) patients.
}

\author{
UmmeShahera', Shahinul Alam², MuniraJ ahan ${ }^{1}$, Afzal un Nessa $^{1}$, Saifullah Munshi ${ }^{1}$, Shahina Tabassum ${ }^{1}$ \\ ${ }^{1}$ Department of Virology, Bangabandhu Sheikh mujib Medical University, Shahbag, Dhaka. ²Department of Hepatology, Bangabandhu Sheikh \\ mujib Medical University, Shahbag, Dhaka.
}

Key word: Antibiotic resistance, Bangladesh, Rajshahi, Salmonella typhi, Salmonella paratyphi A.

\begin{abstract}
Interferon-gamma induced protein 10 (IP-10), a chemokine is suggested to be involved in liver injury during Hepatitis B virus infection (HBV). The increase of IP-10 is a critical step for recruitment of inflammatory cells to the local focus of the liver and hepatopathology. This study was designed to assess the correlation of IP-10 gene expression with HBV-DNA and serumAlanine transaminase(ALT) in patients with cirrhosis and HCC.The study was conducted among 60 patients. The study populationwere divided into four groups ( 15 in each groups)-HBV positive cirnosis, HBV negative cirrhosis, HBV positiveHCC and HBV negative HCC. Expression of IP-10 gene was observed using real time PCR.IP-10 gene expressions in the above mentioned groups were correlated with serum ALT level and HBV vird load.IP-10 gene was significantly higher in HBV-positive patients with HCC than HBVpositive cirrhosis. Similarly, the expression of IP-10 was significantly higher in HBV-positive HCC than HBVnegative HCC patients. However, the expression of IP-10 was reduced in HBV-positive cirrhosis in comparison with HBV-negative cirrhosis.IP-10 gene expression in liver was not correlated with the serum levels of ALT in any of the study groups. HBV- DNA load also did not correlated with IP-10 gene expression in HBV positive HCC and HBV positive cirrhosis patients. This study shows that there was no significant change with the expression of IP-10 gene in any of the study groups with ALT level or viral load, though differential expression of IP-10 gene were observed in cirrhosis and HCC patients.
\end{abstract}

Key words: IP-10, ALT, HBV-DNA, Liver cirrhosis, Hepatocellular carcinoma.

\section{Introduction:}

Hepatitis B virus (HBV) infection is a major health problem world wide. It causes acute and chronic liver disease. Although there is no direct cytopathic effect on hepatocytes, HBV infection induces the infiltration of immune cells, leading to formation of necroinflammatory foci, thus

\author{
Correspondence: \\ Dr. UmmeShahera \\ Medical Officer \\ Department of Virology \\ Bangabandhu Sheikh Mujib Medical University (BSMMU) \\ E-mail: sammamjuhaer@yahoo.com \\ Contact no: 01711345008
}

mediating disease process. ${ }^{1,2}$ Every year about one million people die of HBV-related cirrhosis or HCC. ${ }^{3}$

Serum ALT levels should reflect the degree of liver damage, whereas IP-10 levels may reflect immune activity. ${ }^{4,5}$ It has been recognized that higher ALT levels was a risk predictor for more active immune response against HBV and more extensive hepatocyte damage ${ }^{6,7}$ The extent of hepatocyte necrosis and the degree of ALT elevation do not al ways correlate, HBV DNA could be a important factor than ALT level for the subsequent development of cirrhosis and HCC.8-10

IP-10 or CXCL 10 is a C-X-C chemokine that can be secreted by hepatocytes and sinusoidal endothelium in the liver of 
hepatitis patients. ${ }^{11,12}$ By binding with CXCR3 receptor, IP10 exerts the chemoattracting effect on NK cells, activated T cells, and dendritic cells. ${ }^{13}$ IP-10 may play an important role in trafficking inflammatory cells to the local focus in the liver and induce the development of the chronicity of hepatitis B. Excessive inflammation of local liver tissues in chronic hepatitis B may eventually lead to liver cirrhosis.14In an earlier study, it was observed that IP-10 gene expression is significantly higher in HBV-positive patients with liver cancer than HBV-positive cirrhosis. Similarly, the expression of IP-10 gene is significantly higher in HBV-positive HCC than HBV-negative HCC patients. However, the expression of IP-10 gene is reduced in HBVpositive cirrhosis in comparison with HBV-negative cirrhosis.15 Reduction in IP-10 gene expression is more evident in cimhosis group. It could be concluded that reduced expression of IP-10 gene might be associated with lesser infiltration of immunocompetent cells to liver to avert further damage in cirrhosis than HCC. As increase level of ALT indicates the liver injury (cirrhosis) and increase HBV-DNA indicates the replication status of hepatits $B$ virus during $\mathrm{HCC}$, the purpose of this study was to assess the correlation of IP-10 gene expression with HBV-DNA and ALT in patients with cirrhosis and HCC.

\section{M aterials And M ethods:}

\section{Patient selection and Sample collection:}

The study participants were divided into four groups (15 in each groups), namely HBV positive cirrhosis and HBV positiveHCC as disease groups and HBV negative cirrhosis and HBV negative HCC as control groups. On the basis of Clinically (ascitis, jaundice, oedema, palmer erythema and varicial bleeding), biochemically (HbsAg status, Anti HBC total, serum ALT) and sonographycally diagnosed Cirrhosis and histopathologically diagnosed HCC patients were selected as patients groups. Control groups were recruited in this study who were HBsAg and Anti HBc (total) negative but had cirrhosis and HCC. After obtaining informed written consent, ultrasound guided Fine Needle Aspiration Cytology (FNAC) was performed at the Department of Hepatology of BSMMU by trained Hepatologists. The FNAC samples were collected in RB (RNA binding) buffer solution for extraction of RNA using Total RNA mini kit (Geneaid, Taipe, Taiwan). All the samples were transported under appropriate conditions to the Molecular Laboratory of the Department of Virology, BSMMU, for further procedures.Five $\mathrm{ml}$ of blood was collected from each patient and kept at -70 $0 \mathrm{C}$ for ALT assay and HBV-DNA quantitation. ALT measurement and HBV-DNA quantitation were performedat the Department of Biochemistry and Virology respectively.

\section{Serum ALT and HBV-DNA measurement:}

The levels of serumALT were measured biochemically using an automated analyzer (ALTI Flex ${ }^{\circledR}$ reagent cartridge), by Dimension EXL USA, at the Department of Bio-chemistry, BSMMU.

Five $\mu$ of serum were used to detect HBV-DNA of each patient. At first $5 \mu$ lysis buffer was added to PCR tube, then patient's serum was added. After 10 minutes of incubation, 40 $\mu l$ of master mix was added in the PCR tube. Finally total 50 $\mu \mathrm{l}$ of reaction volume was used for detection of HBV-DNA. PCR was performed with initial denaturation at $95^{\circ} \mathrm{C}$ for 15 min, followedlby denaturation at $95^{\circ} \mathrm{cfor} 15 \mathrm{sec}$, annealing at $57^{\circ} \mathrm{C}$ for $30 \mathrm{sec}$ and lastly, extention at $72^{\circ} \mathrm{C}$ for $30 \mathrm{sec}$. Fluorescence signal were measured during 45 PCR cycles. Serum HBV DNA was measured using Single step Hepatitis B Viral DNA Quantitative Fluorescence Diagnostic Kit (Genebio HBV DNA quantitation Kit, USA) at the Department of Virology, BSMMU.

R NA extraction and real-time PCR: Total 200ul RNA was extracted from FNAC sample using Total RNA mini kit (tissue) (Geneaid, Taipe, Taiwan) according to the manufacturer's instructions. The complementary deoxyribonucleic acid (CDNA) was synthesized using CDNA synthesis Kit (Solis-biodyne, Tartu, Estonia). A total of $5 \mu \mathrm{l}$ of cDNA were usedfor real-time Polymerase chain reaction (PCR). The sel ected gene expression was analyzed using Step One PCR (Applied Biosystem, USA) using $5 \times$ HOT FIREPol Evagreen ${ }^{\circledR}$ qPCR Mixplus (ROX) (Solis-Biodyne, Tartu, Estonia). The primer sequences were used IP-10 sense: 5'GCCTCT-CCCATCACTTCCCTAC-3'; IP-10 antisense: 5'GAAGCAG-GGTCAGAACATCCAC-3' GAPDH sense: 5'ATCCCATCACCATCTTCCAG-3'; GAPDH antisense: 5'ATGAGTCCTTCCACGATACC-3'. Glyceral dehyde 3phosphate dehydrogenase (GAPDH). ${ }^{16}$ was used as endogenous control to normal ize the PCR reaction of selected genes. PCR was performed with initial denaturation at $95^{\circ} \mathrm{C}$ for $15 \mathrm{~min}$, followed by 40 cycles of denaturation at $95^{\circ} \mathrm{C}$ for $15 \mathrm{sec}$, anneal ing at $55^{\circ} \mathrm{C}$ for GAPDH, $53^{\circ} \mathrm{C}$ for IP-10 for 30 $\mathrm{sec}$, and lastly, extention at $72^{\circ} \mathrm{C}$ for $30 \mathrm{sec}$. Fluorescent signal reporter generated in qPCR were measured.

Statistical Analysis: Comparisons between HBV positive cirrhosis and HCC and HBV positive HCC and HBV negative HCC were performed using Wilcoxon Rank Sum (MannWhitney) test. Two-sample t-test was performed between HBV positive cirrhosis and HBV negative cirrhosis. The correlation of IP-10 gene expression with the ALT level and the viral load were analyzed using the Pearson correlation ( $r$ ) testData were analysed with Statistical Program for Social Science (SPSS) version 16.0 software (SPAA Inc, USA). 
pvalue $\varangle .05$ was considered statistically significant and $p$ value $\varangle 0.001$ as highly significant

\section{Results}

A total of 60 patients were included in this study, of whom 49 (81.66\%) were males and 11 (18.33\%) were females. The mean $\pm S D$ of ALT levels of HBV positive HCC, HBV negative HCC, HBV positive cirrhosis and HBV negative cirrhosis were $57.20 \pm 19.93 \mathrm{IU} / \mathrm{L}, 52.27 \pm 13.13 \mathrm{IU} / \mathrm{L}$, $62.07 \pm 45 \mathrm{IU} / \mathrm{L}$ and $48+12.0 \mathrm{IU} / \mathrm{L}$ respectively. The mean viral load of HBV positive HCC was $4.02+1.37$ and HBV positive cirrhosis was $3.52+1.53[\log 10$ (copies/ml)], and this difference was statistically significant ( $p$ value $\varangle 0.01$ ). The most common complaints among patients were ascitis (65\%), palmer erythema $75 \%$, oedema $66.6 \%$ and variceal bleeding in $50 \%$ in HBV positive cirrhosis.

IP-10 was significantly higher in HBV-positive HCC than HBV-negative HCC patients (tablel). The up regulation of IP-10 expression was 19.32 fold in HBV positive HCC patients when compared with HBV negative HCC patients where this was (1.00 fold). (Fold changes not shown in table). Similarly, the expression of IP-10 was significantly higher in HBV-positive patients with HCC than HBVpositive cirrhosis (tablel) ( 6.5 fold vs 1 fold) (Fold changes not shown in table).

However, the expression of IP-10 gene was reduced in HBVpositive cirrhosis in comparison with HBV-negative cirrhosis (figure-1). IP-10 gene expression in liver was not correlated with the serum levels of ALT in any of the study groups. HBV- DNA load did not correlated also with IP-10 gene expression in HBV positive HCC and HBV positive cirrhosis patients (Table ll)

Table I: R elative expression of the IP-10 gene betweenH BV positive HCC and HBV negative HCC and HBV positive HCC and cirrhosis

\begin{tabular}{llcccc}
\hline $\begin{array}{l}\text { Target } \\
\text { Gene }\end{array}$ & Group & Observation & Rank-sum & expected & p-valueGene \\
\hline \multirow{4}{*}{$\begin{array}{l}\text { HBV } \\
\text { positiveHCC }\end{array}$} & 15 & 345 & 232.5 & \\
& $\begin{array}{l}\text { HBV } \\
\text { negativeHCC }\end{array}$ & 15 & 120 & 232.5 & \\
\cline { 2 - 6 } & $\begin{array}{l}\text { HBV } \\
\text { positiveHCC }\end{array}$ & 15 & 345 & 232.5 & \\
& $\begin{array}{l}\text { HBV } \\
\text { negativeHCC }\end{array}$ & 15 & 120 & 232.5 & \\
\hline
\end{tabular}

*Wilcoxon Rank Sum (Mann-Whitney) test were performed in total 60 patients, 15 in each groups (HBV positive HCC, HBV negative HCC, HBV positive HCC and HBV positive Cirrhosis), where $p$ value, $p<0.001$ was considered to be significant.

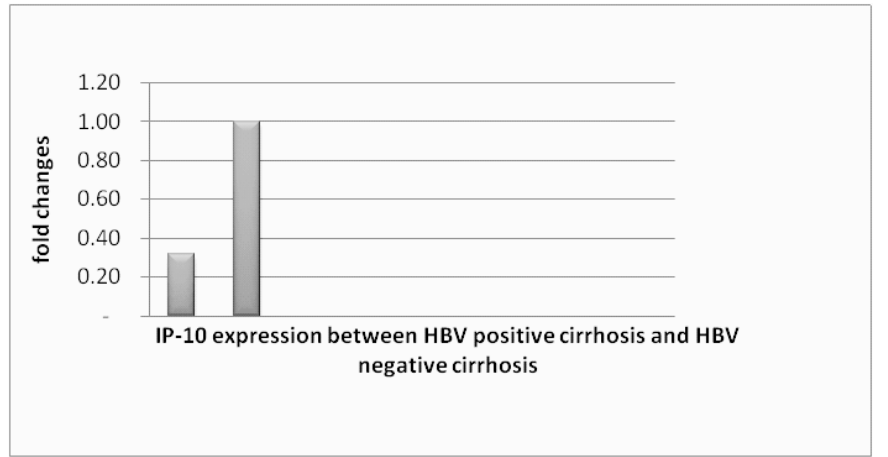

Figure 1: Two-sample t-test was performed between HBV positive cirrhosis and HBV negative cirrhosis.Differences were considered statistically significant where $p$ value was $\varangle 0.05$.

Table II: Correlation of expression of IP-10 gene in liver with serum ALT levels and HBV-DNA in different groups

\begin{tabular}{|c|c|c|c|c|c|}
\hline Variables & Catagories & $\begin{array}{l}\text { HBV } \\
\text { positive } \\
\text { HCC(n=15) }\end{array}$ & $\begin{array}{l}\text { HBV } \\
\text { negative } \\
\text { HCC }(n=15)\end{array}$ & $\begin{array}{l}\text { HBV positive } \\
\text { Cimnosis } \\
(n=15)\end{array}$ & $\begin{array}{l}\text { HBV negative } \\
\text { Cinhosis } \\
(n=15)\end{array}$ \\
\hline \multirow{3}{*}{ IP-10 } & $\begin{array}{l}\text { IP-10 } \\
\text { with ALT } \\
\text { levels }\end{array}$ & -.064 & .004 & .414 & 144 \\
\hline & p value* & .851 & .990 & .205 & .674 \\
\hline & $\begin{array}{l}\text { IP-10 with } \\
\text { HBV-DNA }\end{array}$ & .395 & & -.263 & \\
\hline
\end{tabular}

*Pearsoncorrelation test were done where $p$ val ue, $p \varangle 0.05$ was considered to besignificant.

\section{Discussion}

HBV, being primarily a hepatotrophic virus, may intensify progressive liver injury leading to increased risk of developing liver cirrhosis and HCC. ${ }^{17}$ It has been ascribed that a failure of anti-viral immune response is responsible for the establishment of chronic HBV infection, ${ }^{18}$ although the exact mechanism by which HBV escapes immunity is still unknown. Conversely, HBV-associated liver damage is considered to be the consequence of a protected cytolytic immune response generated against infected hepatocytes. ${ }^{19}$ One of the major role in this process is thought to be the migration of immune cells to infected liver under the influence of chemokine signaling. The chemoattractive activity of IP-10 is observed on monocytes, macrophages, T cells, NK cells, and dendritic cells respectively. ${ }^{20}$ The intrahepatic production of chemokine is supposed to be associated with the recruitment of antigenically nonspecific immunocompetent cells into the liver which can augment the severity of cirrhosis.

The major pathway for viral clearance in liver has been ascribed to the noncytopathic antiviral mechanism of CTLS than killing of HBV infected hepatocytes by CTLs through 
direct contact. This noncytopathic viral clearance occur by inhibition of replication and expression of HBV genome through intrahepatic secretion of IFN-Y. ${ }^{21}$ This studyassessed the gene expression pattern of IP-10 in clinically defined HBV disease categories and to corre late the expression of this gene with serumALT level and HBV-DNA.

In this study, among 60 patients, about $81.66 \%$ were male and it suggests that cirrhosis and HCC is more common in male patient. The HBV-DNA was more in HCC than cirrhosis patients, which proves that viral load increase in HCC. Some clinical features were observed, commonly ascitis, jaundice, palmer erythema, oedema and variceal bleeding in cirhosis patients which is due to portal hypertension.

IP-10 gene stimulates HBV-specific cytotoxic $T$ cells to recruit antigen non-specific lymphomononuclear and polymorphonuclear inflammatory cells within the liver tissue resulting in hepatic necroinflammatory damage and release ALT into the blood. Previous study showed that there was no significant change with the expression of IP-10 gene and ALT leve or viral load. ${ }^{22}$ Although, in the previous study the expression of IP-10 gene is correlated with ALT levels HBV DNA load in patients with $\mathrm{CHB} .{ }^{23}$

The significant drop in the gene expression of IP-10 as observed in our group of cirrhotic subjects might have insinuations in promoting lesser recruitment of immunocompetent cells from peripheral pool to liver to avert further damage.

The expression of IP-10 gene in liver was not correl ated with serum level of HBV-DNA. It was reported that there was a significant increase in serum level and IP-10 gene expression in PBMCs of HBV mediated cirrhosis patients along with increased level of HBV DNA in such patients. ${ }^{24}$ Regarding the involvement of viral components with the expression pattern of IP-10 gene, these data are in contrast to those of. 24,25 This study did not reveal any association between expression pattern of IP-10 gene and serum HBV DNA.

IP-10 can be directly induced by viruses in rat astrocytes and microglias. ${ }^{26}$ and in mouse liver tissues. ${ }^{27}$ so it cannot discount the possibility of direct induction of IP-10 by HBV. Thus it can be conclude that, the extent of hepatocyte injury and the degree of ALT elevation and HBV-DNA count does not necessarily al ways correlate, although IP-10 may be responsible for the molecular pathogenesis and clinical outcome of HBV positive cirrhosis and HCC patients. IP-10 has recently been shown to be a useful biomarker for identifying patients with significant fibrosis ${ }^{28}$ and are positively correlated with liver inflammation. IP-10 is also associated with a decrease in ALT levels ${ }^{29}$. So, IP-10 itself can be used as a prognostic marker for cirrhosis and HCC.

The present study has some limitations. The sample size of cirrhotic and HCC subjects was smaller, stages of liver damage were not biopsy proven and the serum level of IP-10 gene were not measured. However, the study result raises the possibility of undertaking further studies involving larger cohorts of cirrhotics and HCC of both HBV and non viral etiology.

\section{REFERENCES:}

1. Chisari $F$ V, Ferrari C. Hepatits B virus pathogenesis. Annual Review of Immunology 1995; 13: 29-60.

2. Tiollais P, Chamay P, Vyas G N. Biology of hepatitis B virus. Science 1981; 213(4506): 406-411.

3. ElgouhariHM,Abur-RajabTamimiTI, CareyWD."Hepatitis $B$ virus infection:understanding its epidemiology, course, and diagnosis." Cleveland Clinic Joumal Of Medicine 2008; 75(12): 881-889.

4. Kim WR, Flamm SL, Di Bisceglie AM, Bodenheimer HC, Public Policy Committee of the American Association for the Study of Liver D. Serum activity of alanine aminotransferase (ALT) as an indicator of health and di sease. Hepatology 2008; 47: 1363-1370.

5. Deng G, Zhou G, Zhang R, Zhai Y, Zhao W, Yan Z, Deng C, Yuan $X$, Xu B, Dong $X$, Zhang $X$, Zhang $X$, Yao Z, Shen $Y$, Qiang $B$, Wang $Y$, He F. Regulatory polymorphisms in the promoter of CXCL10 gene and disease progression in male hepatitis $B$ virus carriers. Gastroenterology 2008; 134: 716-726.

6. Liaw YF, Leung N, Kao JH, Piratvisuth $T$, Gane E, Han KH, Guan R, Lau GK, Locamini S, Chronic Hepatitis BGWPotA-PAftSotL. Asian-Pacific consensus statement on the management of chronic hepatitis B: Hepatology International 2008; 2: 263-283.

7. Yang $\mathrm{HI}$, Yeh $\mathrm{SH}, \mathrm{Chen} \mathrm{PJ}$, Iloeje UH, Jen $\mathrm{CL}, \mathrm{Su}$ J, Wang LY, Lu SN, You SL, Chen DS, Liaw YF, Chen CJ; REVEAL-HBV Study Group. Associations between hepatitis B virus genotype and mutants and the risk of hepatocellular carcinoma. Joumal Of National Cancer Institute 2008; 100: 1134-1143.

8. Chen CJ, Yang HI, Su J, Jen CL, You SL, Lu SN, et al. Risk of hepatocellular carcinoma across a biologic gradient of serum hepatitis B virus DNA leve. JAMA. 2006;295:65-73.

9. Yang HI, Lu SN, Liaw YF, You SL, Sun CA, Wang LY, et al. Hepatitis $B$ e antigen and the risk of hepatocellular 
carcinoma. New England Journal of Medicine. 2002;347:168-74.

10. Iloeje UH, Yang HI, Su J, Jen CL, You SL, Chen CJ. Predicting cirrhosis risk based on the level of circulating hepatitis B viral load. Gastroenterology 2006;130:678-86.

11. Nanumi S, Tominaga Y, Tamaru M, Shimai S, Okumura $\mathrm{H}$, Nishioji $\mathrm{K}$, Itoh $\mathrm{Y}$, Okanoue T. Expression of IFNinducible protein-10 in chronic hepatitis. J ournal of Immunology. 1997; 158 (11): 5536-554

12. Nishioji K, Okanoue T, Itoh Y, Narumi S, Sakamoto M, Nakamura H, Morita A, Kashima K. Increase of chemokine interferon-inducible protein-10 (IP-10) in the serum of patients with autoimmune liver diseases and increase of its mRNA expression in hepatocytes. Clinical and Experimental of Immunology 2001; 123 (2): 271-279.

13. Neville L. F, Mathiak G, Bagasra O. Cytokine Growth Factor. Review 1997; 8: 207-219.

14. Wang J, Zhao JH,Wang PP, Xiang GJ. Hepatobiliary Pancreat Disease International 2008;7(1):45-50.

15. Shahera U, Munshi S, Jahan M, Nessa A, Alam S, Tabassum S. IP-10, p53 and Foxp3 expression in hepatocytes of chronic hepatitis B patients with cirrhosis and hepatocellular carcinoma (HCC).Euroasian Joumal Of Hepato-gastroenterology ; 2016;6(2):149-153.

16. Wang J, Zhao J, Wang $P$, Xiang G. Expression of CXC chemokine IP-10 in patients with chronic hepatitis B. Hepatobilliary and pancreatic diseases International 2008; 7(1): 45-50.

17. Zeremski M, Petrovic LM, Talal AH. The role of chemokines as inflammatory mediators in chronic hepatitis $C$ virus infection. Journal of Viral Hepatitis 2007; 14(10): 675-687.

18. Ganem D, Prince AM. Hepatitits B virus infection-natural history and clinical consequences. New England J oumal of Medicine 2004; 350:1118-1129.

19. Rehermann B, Nascimbeni M. Immunology of hepatitis $B$ virus and hepatitis $C$ virus infection.National Review Immunology 2005; 5 92):215-229.

20. Robek MD, Boyd BS, Wieland SF, Chisari FV. Signal transduction pathways that inhibit hepatitis B virus replication. Procedings of National academy of Sciences 2004; 101(6): 1743-1747.
21. Wieland, S., Thimme, R., Purcell, R.H., \& Chisari, F.V. Genomic analysis of the host response to hepatitis B virus infection. Procedings of National academy of Sciences2004:101(17):6669-6674.

22. Shravanthi G.V, Mukherjee R.M. Reduced Expression of Human Chemokine Genes RANTES and IP-10 in Hepatitis B virus Mediated Cirrhosis of Liver. Journal of Biology and LifeScience. 2012; 3(1): 220-231.

23. Deng, G., Zhou, G., Zhang, R., Zhai, Y., Zhao, W., Yan, Z., Deng, C.,Yuan, X., Xu, B., Dong, X., et al.. Regulatory polymorphismsin the promoter of CXCL10 gene and disease progression in malehepatitis $B$ virus carriers. Gastroenterology 2008; 134: 716-726.

24. Wang, J., Wang, P.P., Xiang, G.J., \& Hu, X.B. Relationship between theexpression of IP-10 and IP-10 mRNA in peripheral blood and HBV DNA level inpatients with cirrhosis. Hepatobiliary Pancreatic Diseases International 2010: 9,:280- 286.

25. Zhang, K., Xu, Q.H., Chen, L.B., Shu, X., Chen, N., \& Li, G. Correlation of serum chemokine RANTES level with serumbiochemical indices, HBeAg and HBV DNAload in patients with chronic hepatitis $B$. Chinese Journal Of Experimental and Clinical Virology 2009; 23 :188-190.

26. Vangri P, Farber JM. IFN and virus-inducible expression of an immediate earlygene, crg-2/IP-10, and a delayed gene, I-Aa, in astrocytes and microglia.J ournal of Immunology 1994; 153:1411-1418.

27. Amichay D, Gazzinelli RT, Karupiah G, Moench TR, Sher A, Farber JM. Genesfor chemokines MuMig and Crg-2 are induced in protozoan and viral infections in response to IFN-g with patterns of tissue expression that suggest nonredundant roles in vivo. Journal of Immunology 1996; 157:4511-4520.

28. Yoshio S, Sugiyama M, Shoji $H$, Mano $Y$, Mita E, Okamoto T, Matsuura Y, Okuno A, Takikawa O, Mizokami M, et al. Indoleamine2,3-dioxygenase as an effector and an indicator of protective immune responses in patients with acute hepatitis B. Hepatology2016; 63:83-94.

29. Sevgi D.Y, Bayraktar B, Gunduz A, Ozguven B.Y, Togay $A$, Bulut $E$, Uzun N, and Dokmetas I. Serum soluble urokinase-type plasminogen activator receptor and interferongamma induced protein 10 levels correlate with significant fibrosis inchronic hepatitis $\mathrm{B}$. Wien. Klin. Wochenschr. 2016;128: 28-33. 